\title{
Aid application multicriteria the decision based on AHP Method and Fuzzy Logic in commercial land selection
}

\section{Aplicação do auxílio multicritério à decisão baseada nos métodos AHP e Lógica Fuzzy na seleção de terrenos comerciais}

ISSN 0104-530X (Print) ISSN 1806-9649 (Online)

\author{
Nilson Brandalise ${ }^{1}$ (D) \\ Amanda Sexto Alexandre Pereira ${ }^{2}$ (D) \\ Luiz Carlos Brasil de Brito Mello ${ }^{1,3}$ (D)
}

\begin{abstract}
How to cite: Brandalise, N., Pereira, A. S. A. \& Mello, L. C. B. B. (2019). Aid application multicriteria the decision based on AHP Method and Fuzzy Logic in commercial land selection. Gestão \& Produção, 26(3), e3243. https://doi.org/10.1590/0104-530X3243-19
\end{abstract}

\begin{abstract}
The objective of this article is to select land for commercial buildings in Rio de Janeiro city using multiple criteria decision-making techniques. The techniques used were based on the Analytic Hierarchy Process (AHP) and Fuzzy Logic methods. These methods were chosen because of functionality, flexibility and great application in engineering problems for decision making involving multiple criteria. Its application was made through an opinion survey with expert builders, where 6 ( six) factors for evaluation were selected in 10 (ten) commercial land alternatives. For the analytical operation of the methods, the software used were: Super Decisions and MATLAB ${ }^{\circledR}$, respectively for each method, presenting the factors classified, in order of priority, in the selection of land, and ranking of the alternatives according to the defined scenario, facilitating in this way the process of selection of land for buildings, establishing a scientific way for the decision process.
\end{abstract}

Keywords: Decision-making; Multicriteria decision; Analytic Hierarchy Process (AHP); Fuzzy Logic; Real estate market; Land selection.

Resumo: O objetivo deste artigo é a seleção de terrenos para edificações comerciais na cidade do Rio de Janeiro, por meio do uso de técnicas de múltiplos critérios de tomada de decisão. As técnicas utilizadas tomaram como base os métodos: Analytic Hierarchy Process (AHP) e a Lógica Fuzzy. Estes métodos foram escolhidos devido à funcionalidade, flexibilidade e grande aplicação em problemas de engenharia para tomada de decisão envolvendo múltiplos critérios. Sua aplicação foi feita através de uma pesquisa de opinião com especialistas construtores, onde foram selecionados 6 (seis) fatores para avaliação, em 10 (dez) alternativas de terrenos comerciais. Para a operacionalização analitica dos métodos foram utilizados os softwares: SuperDecisions e MATLAB ${ }^{\circledR}$, respectivamente para cada método, apresentando os fatores classificados, por ordem de prioridade, na seleção de terrenos, e ranking das alternativas de acordo com o cenário definido. Desta forma, é facilitado o processo de seleção de terrenos para edificações, estabelecendo uma forma científica para o processo de decisão.

Palavras chave: Tomada de decisão; Análise multicritério; Analytic Hierarchy Process (AHP); Lógica Fuzzy, Mercado imobiliário; Seleção de terrenos.

\section{Introduction}

The increase in the demand for housing in big urban centers caused a considerable appreciation of the square meter in these places. However, the

demand for both real estate and land available for construction continues with great demand. All this valorization has brought to light a need to improve

\footnotetext{
${ }^{1}$ Programa de Pós-graduação em Engenharia Civil, Escola de Engenharia, Universidade Federal Fluminense - UFF, Rua Passo da Pátria, 156, $3^{\circ}$ andar, Sala 365, Bloco D, São Domingos, CEP 24210-240, Niterói, RJ, Brasil, e-mail: nilson_01@yahoo.com.br

${ }^{2}$ Departamento de Engenharia de Produção, Escola de Engenharia Industrial Metalúrgica de Volta Redonda, Universidade Federal Fluminense - UFF, Av. dos Trabalhadores, 420, CEP 27255-125, Volta Redonda, RJ, Brasil, e-mail: amanda.sexto@gmail.com

${ }^{3}$ Departamento de Engenharia de Produção, Escola de Engenharia, Universidade Federal Fluminense - UFF, Rua Passo da Pátria, 156, $3^{\circ}$ andar, Sala 365, Bloco D, São Domingos, CEP 24210-240, Niterói, RJ, Brasil, e-mail: luiz.brasil@gmail.com
}

Received Aug. 26, 2016 - Accepted May 22, 2017

Financial support: None. 
research on the availability of land for a construction company or a builder to acquire, for the usage of the area, for the construction of buildings. The intense and accelerated urbanization results in problems such as the scarcity of suitable areas for buildings in large urban centers.

The main problems encountered by construction companies indicated that the availability of land was one of the problems of companies, being more accentuated in small construction companies (CNI, 2010; Garcia, 2014).

The ideal land location studies encompass the set of procedures that work on regional and urban scale, reaching determinants that will lead the choice of terrain, involving complex physical and legal issues (Carvalho \& Barreto, 2005). In addition to assessing value, dimensions, location, and other factors, it is necessary to verify if soil and water of the site present impacts generated by previous activities (Arend et al., 2011). The innumerable attributes make it difficult for companies in the industry to choose quickly and at the same time effective for companies in the sector in relation to the choice of land. Using decision-making models is possible to analyze numerous variables present in the problem and to facilitate the process, making the choice of a more objective and conscious.

In a survey carried out in the databases of the systems: DOAJ; Emerald Journal; InderScience online and ScienceDirect Journals (Elsevier), using key words associated with the theme, were observed the following quantities of published articles, according to table 1 , with no localization of similar or relation with the theme selection of lands for commercial buildings.

The selection of land for buildings is of great importance for the construction sector, with great possibilities of return. There will always be a viable project, regardless of whether the lot is residential or commercial. In this way, the theme arose from a difficulty faced by the researcher, in reading other works and the theory itself. (Prodanov \& Freitas, 2013).

The definition of selection through decision-making methods positively influences the sector's investors (Leite \& Veloso, 2012). The article proposes the use of methods that help in decision making to select land for buildings in Rio de Janeiro city, revealing

Table 1. Keyword Survey in Database.

\begin{tabular}{lc}
\hline \multicolumn{1}{c}{ DATA BASE } & $\begin{array}{c}\text { Quantity per Key } \\
\text { Words }\end{array}$ \\
\hline DOAJ & 36 \\
EmeraldJournals & 264 \\
InderScience Online & 547 \\
ScienceDirectJournals (Elsevier) & 1550 \\
\hline
\end{tabular}

Source: Prepared by the authors (2017). through the comparison of specific methods, the best possibilities of investment in the sector. The methods applied were the Analytic Hierarchy Process (AHP) and the Fuzzy Logic. These methods were chosen because of the broad theoretical framework and easy access, allowing a detailed application and a high degree of reliability of the final results, besides the extensive applicability, simplicity, ease of use and great flexibility (Ho, 2008; Barin et al., 2010). Thus, it was possible to make a comparative between the types of terrain from these two methods of decision making and to present a ranking of the alternatives according to the defined scenario.

The research intends, taking into account measurable factors, to answer the following question: Are the results of the decision-making methods satisfactory in the selection of commercial lands in Rio de Janeiro city? The present article has as general objective the selection of commercial lands in Rio de Janeiro city through the use of multiple criteria decision-making techniques. The specific objectives are as follows:

a) To study specific methods related to Decision Making;

b) To analyze effectiveness of the decision-making methods evaluated, when applied, to select commercial lands in Rio de Janeiro city, and

c) Make a comparative between the types of terrain from two (2) methods of decision making and present a ranking of alternatives according to the defined scenario.

The article is structured in the following way: the introduction broadly addresses the characteristics of the construction industry and importance of decision-making methods, and explains objectives, justifications and research question. Next, a bibliographical review is made contextualizing concepts of civil construction, land for buildings, characteristics of Rio de Janeiro city, decision making, AHP method and Fuzzy Logic. Subsequently, the data collection and description of factors for application of methods are presented, making a detailed analysis of the data collected, with the application of methods used. Finally, it is concluded, showing limitations and difficulties encountered, recommendations and suggestions for future work and bibliographical references.

\section{Civil construction and lands for buildings}

According to the Ministry of Education, in the publication of national curricula of professional education, (MEC, 2000, p.9), Civil Construction area covers all activities of production of works. Included in this area are activities related to planning and 
design, execution and maintenance and restoration of works in different segments, such as buildings, roads, ports, airports, shipping channels, tunnels, building installations, sanitation works, foundations and of land in general, [...]. Also, according to the publication, the Civil Construction area has interfaces with several other professional areas, having an interface with the Management area, clearly present in management activities of execution and maintenance of works.

Civil construction was a strong driver of recent growth in Brazil, with Gross Domestic Product - GDP showing an accumulated evolution of $47 \%$ in period 2003-2013, against $46 \%$ of the economy as a whole. If the current investment rate is relatively low, around $18 \%$ of GDP, in the period under consideration, is important to note that construction accounted for approximately $40 \%$ of this investment.

The Construction Industry is one of the most important sectors for the economy of any country. In recent years, this segment has undergone a significant expansion process and, despite effects of the international crisis, this dynamism has been underpinned, implying new challenges. According to data from Getulio Vargas Foundation (FGV), to cover housing deficit by 2022, investments should accumulate more than $\mathrm{R} \$ 3$ trillion. The state of Rio de Janeiro, in turn, is in the spotlight as a major hub of public and private investment. (Sistema Firjan, 2013).

The construction industry depends directly on management of information and flow of resources (people, materials and equipment). Companies in the construction sector, because they are part of a very complex environment, require their managers to have a more specific approach. This sector needs to have an extreme capacity for change to adapt to the new times, through the improvement of its administrative processes and standards, seeking a greater competitiveness in the market (Xavier et al., 2014).

There are many aspects to characterize a terrain, Camposinhos (2006), among the main ones: the legal framework, accessibility, topography and factors of appreciation or devaluation.

In defining the constructive capacity of a land, is necessary to know clearly its legal-administrative status. It is responsibility of the appraiser to verify if there are any liens registered in registries of the land register, such as liens, mortgages and their value. Their knowledge cannot be omitted and in the uncertainty of their possible existence should be expressed the proper reservations. Legal documents, municipal plans, detailed plans and the municipal services themselves should be consulted in order to verify any restrictions that might affect the constructive capacity of the land (Camposinhos, 2006).

According to Camposinhos (2006), it is fundamental to confirm if the land has direct accessibility by a confronting road or if access is conditioned by the passage through another terrain. The available widths and slopes of accesses can condition the circulation of priority vehicles, fire engines and ambulances. Irregular terrains are less well-off, so they are less valued. There are many criteria to be considered for building a particular project. The selection of a land must take into account from the essential aspects of size and location to more specific factors such as physical and legal limitations that directly influence design and can make a certain construction plan unfeasible.

\section{Characteristics of Rio de Janeiro city}

According to Rio de Janeiro (2015), Rio de Janeiro city is located at $22^{\circ} 54^{\prime} 23^{\prime \prime}$ south latitude and $43^{\circ} 10^{\prime} 21^{\prime \prime}$ west longitude, being the capital of the State of Rio de Janeiro. The city is bathed by the Atlantic Ocean to the south, by the Guanabara Bay to the east and by the Sepetiba Bay to the west. Its maritime divisions are more extensive than terrestrial ones. The area of the municipality of Rio de Janeiro is $1,255.3 \mathrm{~km}^{2}$, including the islands and the continental waters. It measures from east to west $70 \mathrm{~km}$ and from north to south $44 \mathrm{~km}$. The municipality is divided into 32 Administrative Regions with 159 districts and has 6,453,682 inhabitants (IBGE, 2014).

Still according to the Rio de Janeiro (2015), the Rio de Janeiro relief is affiliated with the Serra do Mar system, covered by Mata Atlântica forest. It is characterized by striking contrasts, mountains and sea, forests and beaches, rocky cliffs rising abruptly and extensive shorelines. Rio de Janeiro presents three important mountainous groups, plus a few sets of smaller mountain ranges and isolated hills amidst the plains surrounded by these main massifs.

Rio de Janeiro is the city with the second largest GDP in Brazil, it also holds the 30th largest GDP of the planet, which, according to IBGE data, in 2007, equivalent to $5.4 \%$ of the national total. The services sector comprises the largest share of GDP (65.52\%), followed by tax collection (23.38\%).

\section{Decision making}

Decision making is the process of identifying a problem or an opportunity and selecting a course of action to solve it (Lachtermacher, 2007).

According to Gomes (2007), multicriteria support for decision-making has a crucial role, of an eminently technical nature, in decision-making concerning complex decision-making processes. Once one deals with multiple - and conflicting - decision criteria, one can imagine that the good solution sought will, to varying degrees, address the various objectives that characterize the decision problem. 
According to Lachtermacher (2007), several advantages can be cited when the decision maker uses a modeling process for decision making: a) Models force decision makers to make explicit their objectives; b) The models force the identification and storage of the different decisions that influence the objectives; c) Models force the identification of the variables to be included and in what terms they will be quantifiable, and d) Models force the recognition of the limitations.

Among the main methods of decision making are AHP method and Fuzzy Logic. The Fuzzy Logic or diffuse Logic was first proposed by Zadeh (1965). The use of fuzzy Logic in multicriteria analyzes allows the simulation of the human form of reasoning from the collection of real data and the implementation of the operator knowledge (specialist) applied to the linguistic formulation of the fuzzy system (Mendel 1995).

\subsection{AHP Method}

One of the first methods developed to solve decision-making problems in the presence of multiple criteria, quantitative and qualitative, was the best-known hierarchical method of analysis, such as the AHP method, or simply the AHP (Analytical Hierarchy Process). The AHP was created in the 1970s by the then professor of the University of Pennsylvania, Thomas L. Saaty (Gomes, 2007).

The basic premise of the AHP method is that a complex decision system must be defined according to a hierarchical structure composed of several levels, which comprise elements whose characteristics can be considered similar. This type of problem structuring allows such characteristics to be easily identified, especially in cases where the purpose of the decision system is to select alternatives according to multiple attributes. One of the main aspects of the AHP method is that it recognizes subjectivity as inherent in decision problems and uses value judgment as a way to treat it scientifically. This property is extremely useful when it is difficult to obtain formations from probabilistic data (Faria \& Augusto, 2013; Veras, 2014).

The AHP technique has been extensively studied and refined since its development. It provides a comprehensive and rational procedure for structuring a problem, to represent and quantify its elements, to relate these elements to the overall goals, and to evaluate alternative solutions. It is used throughout the world in a wide variety of decision situations, in fields such as government, business, industry, health, and education (Veras, 2014).

AHP functioning is similar to the natural method of functioning for solving problems of the human mind, whose knowledge is considered as important as the data collected. The method is widely used in multicriteria decision making because of its simplicity and ease of operations.

The AHP method application can be divided into five steps: a) Construction of the hierarchical decision; b) Comparison between elements of the hierarchy; c) Relative prioritization of criteria; d) Verification of consistency of priorities, and, e) Calculation of global values of preference.

The hierarchy structure is presented in Figure 1. The decision goal is the general objective to be achieved, followed by the criteria associated with the decision problem and the available alternatives that best fit the problem studied.

After the hierarchy construction it is necessary to establish priorities among the elements present in each level. For Costa (2002), prioritization of AHP is based on the human being's ability to perceive relationship between observed objects and situations by comparing pairs under a particular focus or criterion (parity judgments). In AHP, it is possible to evaluate the prioritization model constructed for its consistency.

They are comparisons in pairs between the various elements of hierarchy, from the alternatives - with respect to the objectives or criteria situated immediately above them - to the objectives or criteria placed at the penultimate level of the hierarchy - being these objectives or criteria compared to each other, from the point of view of the objective to be satisfied at a higher level (Gomes, 2007).

The Saaty Fundamental Scale of value for parity judgments, according to table 2, varies from 1 to 9 , varies between the equal importance of the activities to the absolute importance of one activity in relation to the other, where each element is associated with a priority value over other elements, allowing the comparison of alternatives.

The results of the comparisons are presented in the matrix form represented in Figure 2, with the elements of the judgment matrix A satisfying conditions $\mathrm{a}, \mathrm{b}$ and $\mathrm{c}$.

Therefore, the decision maker should make $n(n-1) / 2$ comparisons, where $n$ is the number of elements of the level analyzed. In the square matrix, we have $a_{i j}$ for $i=1,2, \ldots, n$ and $j=1,2, \ldots, n$. These matrices are always reciprocal positive. Peer-to-peer comparisons are performed at all hierarchical levels. Each element $a_{i j}$ of the line vector of the dominant matrix represents domination of alternative $\mathrm{A}_{i}$ over alternative $\mathrm{A}_{j}$. The main diagonal of the dominant matrix is filled with a stipulated value, which represents the non-dominance of one alternative over another (Gomes et al., 2004).

The resolution of matrix A results in the auto priority vector, which expresses the relative amounts of each criterion, or weights. The most recommended form of computation is to raise the matrix to arbitrarily 


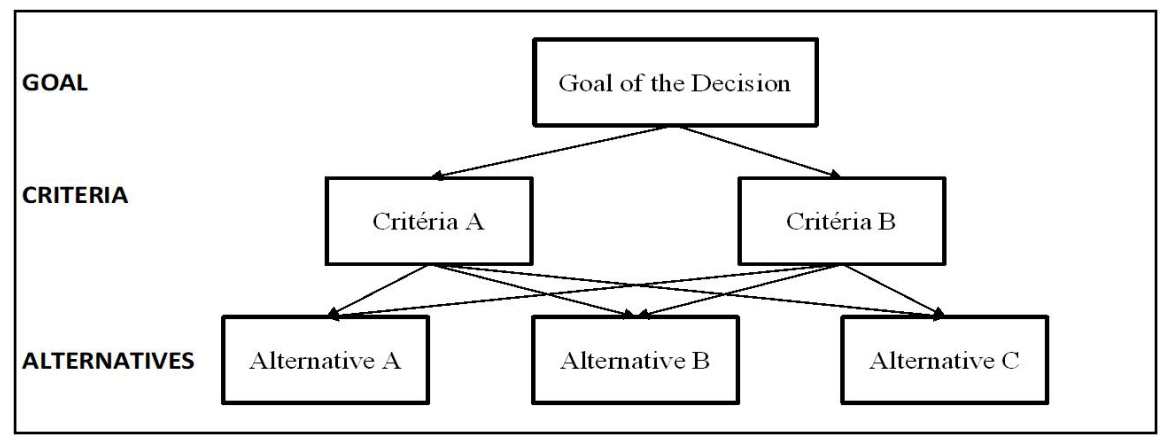

Figure 1. Generic hierarchical structure of decision problems. Source: Adapted from Saaty (1986, p. 842), by the authors (2017).

Table 2. Saaty Fundamental Scale.

\begin{tabular}{|c|c|c|}
\hline 1 & Equal importance & Both activities contribute equally to the goal. \\
\hline 3 & Small importance of one over the other & $\begin{array}{l}\text { Experience or judgment favors one activity } \\
\text { slightly in relation to the other. }\end{array}$ \\
\hline 5 & Large or essential importance & $\begin{array}{l}\text { Experience or judgment strongly favors one } \\
\text { activity over another. }\end{array}$ \\
\hline 7 & Very large importance or demonstrated & $\begin{array}{l}\text { One activity is very strongly favored over the } \\
\text { other. It can be demonstrated in practice. }\end{array}$ \\
\hline 9 & Absolute Importance & $\begin{array}{l}\text { Evidence favors one activity over another, with } \\
\text { the highest degree of safety. }\end{array}$ \\
\hline $2,4,6,8$ & Intermediate Values & $\begin{array}{l}\text { When you are looking for a compromise } \\
\text { condition between two settings. }\end{array}$ \\
\hline
\end{tabular}

Source: Adapted from Saaty (1986, p. 843), by the authors (2017).

$$
A=\left[\begin{array}{cccc}
1 & a_{12} & \cdots & a_{1 n} \\
1 / a_{21} & 1 & \cdots & a_{2 n} \\
\vdots & \vdots & \cdots & \vdots \\
1 / a_{n 1} & 1 / a_{n 2} & \cdots & 1
\end{array}\right] \text {, where: }
$$

$$
\begin{aligned}
& a_{i j}>0 \Rightarrow \text { positive } \\
& a_{i j}=1 \therefore a_{j i}=1 \\
& a_{i j}=1 / a_{j i} \Rightarrow \text { reciprocal } \\
& a_{i k}=a_{i j} \cdot a_{j k} \Rightarrow \text { consistency }
\end{aligned}
$$

Figure 2. Generic decision matrix, with its respective conditions. Source: Marins et al. (2009).

high powers, dividing the sum of each row by the sum of the elements of the matrix that is, normalizing the results (Saaty, 1991; Gartner \& Gama, 2005).

In some problems, the restriction of pair wise comparisons on a scale of 1 to 9 forces the decision maker to make inconsistencies, when $\mathrm{A}$ is considered five times more important than $\mathrm{B}$, and $\mathrm{B}$ is five times more important than $\mathrm{C}$, then to being consistent, A should be 25 times more important than $C$, but this is not possible by the scale used (Gomes, 2007).

Thus, according to Costa (2002), one way of measuring intensity or degree of inconsistency in a matrix of joint judgments is to evaluate how much the greater eigen value of this matrix departs from the order of the matrix. Inconsistency is an inherent fact to the human being. Therefore, there must be a tolerance for its acceptance. It is proposed to accept judgments that generate an inconsistency with IC $<0.1$ (Saaty, 1991).

Based on the relative amounts of the criteria and the preference levels of the alternatives, the total value of each alternative, by a weighted sum operation, equation 1 :

$$
V(a)=\sum_{j=i}^{n} w_{j} v_{j}(a)
$$

With $\sum_{j=i}^{n} w_{j}=1$ and $0<w_{j}<1(j=1, \ldots, n)$, where $V(a)$ is the global value of the alternative analyzed; $w_{j}$ is the relative importance of criterion $j ; v_{j}$ is the preference level of the alternative in criterion $j$ (Gartner \& Gama, 2005). 


\subsection{Fuzzy Logic}

Diffuse Logic (or Fuzzy Logic) is a branch of mathematics that deals with uncertainties in simulating process of human reasoning. It is based on the fact that decision making is not always a matter of true and false. It usually involves intermediate areas where the term "maybe" is more appropriate (Rainer \& Cegielski, 2012).

The concept of a Fuzzy set was introduced in 1965 by Lotf A. Zadeh. It comprises ambiguous situations, which cannot be processed through the computational logic based on Boolean logic (Marques et al., 2005).

There are three main steps for a set of variables to be transformed into something distinguishable within the Fuzzy Logic technique. The first step is fuzzification of each variable. This is a stage in which the antecedents of the "IF-THEN" rules and the rules themselves are detailed, that is; variables along with their rules are transformed into linguistic variables to bring degrees of relevance of an object into the set fuzzy correlation (Marques et al., 2005).

Relevance of an element in a fuzzy set is not a matter of affirmation or negation, but a matter of degree. This degree represents a level of compatibility of the element on the set, in which the value zero means non-participation, the value one means full participation and other values between zero and one means partial participation. The practical number of membership functions is between 2 and 7 for each fuzzy set (representing each of the parameters in question). The greater the number of functions, the greater the accuracy. However, a greater number of pertinence functions lead to a greater number of rules, requiring a much more significant computational demand (Barin et al., 2010).

Thus, according to Garcia et al. (2007), $\mu_{A}(x)$ is the membership function of the element $x$ in the set $A$, whose domain is $x$ and the counter domain, the interval [0;1], a fuzzy set ${ }_{A}$ in $X$ is a set of ordered pairs, equation 2 , where:

$$
A=\left\{\left(x, \mu_{A}(x)\right) \mid x \in X\right\}
$$

The types of fuzzification systems, also known as fuzzy controllers, are known as Mamdani and Takagi-Sugeno. The main difference between these two systems is form of data output - generation of the final results (Barin, 2012).

The second step is inference (fuzzy inference). This step consists of determining the force that each rule has, based on the variable, for the fixation of the calculation algorithm. The recommendation deriving from this inference fixes the degree of pertinence or, the strength of a set of variables, to produce a value between 0 and 1 (Marques et al., 2005).

According to Garcia et al. (2007), a fuzzy inference, consider fuzzy sets $A_{1}, A_{2}, B_{1}, B_{2}, C_{1}$ and $C_{2}$, the input variables $x$ and $y$ and output $z$. A possible rule base would be, equation 3 :

$$
\begin{aligned}
& I F x \in A_{1} E_{y} \in B_{1} T H E N z \epsilon C_{I} \\
& I F x \in A_{2} E_{y} \in B_{2} T H E N z \epsilon C_{2}
\end{aligned}
$$

Since $x \in A$ results in the degree of pertinence of the element $x$ in relation to the fuzzy set $A$ and the logical operators "AND" and "OR" are defined more commonly, respectively, by the minimum and the maximum among the degrees of pertinence, that is, equation 4:

$$
\begin{aligned}
& \text { connective } A N D: x \in A \wedge y \in B=\min \left\{\mu_{A}(x), \mu_{B}(y)\right\} \\
& \text { connective } O R: x \in A \wedge y \in B=\max \left\{\mu_{A}(x), \mu_{B}(y)\right\}
\end{aligned}
$$

The results obtained with the application of the different rules are aggregated through the connective $\mathrm{OR}$, that is, the maximum values are considered for the pertinence degrees of the output variable in relation to a given fuzzy set.

The last step is the establishment of the recommendations (defuzzification). The defuzzification consists in formalization of a given abrupt (non-fuzzy) number representative of the fuzzy set resulting from the application of the rule base. The COG (center of gravity), which provides the bicuspid of the fuzzy set obtained by the aggregation.

\section{Research method}

For the present article, the multicriteria analysis is done by the AHP and Fuzzy Logic methods. The methods have a broad theoretical framework and easy access, allowing a detailed application and a high degree of reliability of the final results, which will be compared to the defined scenario.

According to the research method classification proposed by Bertrand \& Fransoo (2002), in Table 3, this is a quantitative axiomatic research with application of descriptive empirical modeling. Quantitative axiomatic research generates knowledge about certain variables of the model according to the guidelines regarding the behavior of other variables of the model itself. For this, it relies on formal methods in its specific areas, such as: mathematics, statistics and computation (Bertrand \& Fransoo, 2002).

In the initial phase, that is, the Conceptual Model, the conceptual models of the problem are created. You choose problem scope, models to be solved and their variables. In the present study the conceptual models are based on the Saaty model, for AHP and the Zadeh model, for Fuzzy Logic.

In the second phase, the quantitative models are constructed, this phase corresponds to the creation of the Hierarchical Structure, for AHP, and creation of Rules for the Fuzzy Logic, based on the theoretical reference. 
Table 3. Research methodology through the phases of quantitative axiomatic research.

\begin{tabular}{|c|c|c|}
\hline \multicolumn{2}{|c|}{ Phases of Axiomatic Research } & \multirow{2}{*}{ Phases of the Present Research } \\
\hline Phase & Characteristics & \\
\hline Conceptual Model & $\begin{array}{l}\text { The conceptual models of the problem } \\
\text { are created. You choose the scope of the } \\
\text { problem, the models to be solved and their } \\
\text { variables. }\end{array}$ & $\begin{array}{l}\text { The conceptual models are based on the } \\
\text { Saaty model, for the AHP and the Zadeh } \\
\text { model, for the Fuzzy Logic. }\end{array}$ \\
\hline Scientific Model & Quantitative models are constructed. & $\begin{array}{l}\text { This phase corresponds to the creation of } \\
\text { the Hierarchical Structure, for the AHP, and } \\
\text { the Rules for Fuzzy Logic, based on the } \\
\text { theoretical reference. }\end{array}$ \\
\hline Solution & Mathematical methods are applied. & $\begin{array}{l}\text { Execution of the AHP model, through } \\
\text { SuperDecision software and Fuzzy Logic, } \\
\text { through MATLAB }{ }^{\circledR} \text { software. }\end{array}$ \\
\hline $\begin{array}{l}\text { Reality, Problem } \\
\text { Situation }\end{array}$ & The results of the models are compared. & $\begin{array}{l}\text { The results of the AHP and Fuzzy Logic } \\
\text { models are presented in ranking form, and } \\
\text { the alternatives can be compared }\end{array}$ \\
\hline
\end{tabular}

Source: Prepared by the authors (2015).

Also, at this stage, the data were collected through a real estate portal, a real estate channel Canal do Imóvel (2015) with searches made for every city in Rio de Janeiro, in May, 2015. A database with 73 (seventh-three) land for buildings and commercial was elaborated. For the present study only commercial lands were selected, resulting in 10 (ten) alternatives.

The choice and relevance of the criteria for evaluating land alternatives were defined, through consultation with building experts, 2 (two) professionals in the construction sector, in the form of an interview, through an open questionnaire, containing the following questions raised:

1- What are the main factors for choosing a building land?

2- What is the prioritization of these factors (order of importance) for commercial buildings? What is the justification for this prioritization?

The interviews were answered from the point of view of 1 (one) investor in the land purchase/ investment process for commercial buildings.

In the third phase, the Solution phase, where the mathematical methods are applied, the execution and analysis of the AHP method was performed through the free access software SuperDecisions, developed by Thomas Saaty. The system based on Fuzzy Logic was implemented in MATLAB $^{\circledR}$ software, version 6.5, as supplement, by Mamdani method, whose antecedent and consequent are values of linguistic variables, expressed through fuzzy sets. Both evaluated the same alternatives using the same factors.

The fourth and last phase, where it deals with the Reality, Situation Problem, after the realization of the methods, the best alternatives were presented, allowing a comparison of the results obtained by the different methodologies.

\section{Data survey}

The interviews for selection and prioritization of the criteria were performed separately and through an open questionnaire. The characteristics of the professionals interviewed are as follows: Specialist 1: male, 45 years, investor of the buildings sector and Specialist 2: male, 29 years old, architect, works in the building sector.

The selection of factors was the same for the two interviewees, resulting in: location, price, dimensions, surroundings, form and documentation. The opinions were different in the prioritization of the factors. While the specialist 1 considered the price as one of the most important criteria, the specialist 2 defined the price as a variable factor, negotiable, giving priority to the fixed factors: location, dimensions and surroundings. In Table 4, the complete prioritization of the factors by the interviewees.

The criterion of price is decisive, but it is directly related to location. Thus, considering the great variability of price in buy/sell process and how much it is possible to offer/bargain, the evaluation and application of the methods will be based on the Specialist 2 scenario, where the most exact factors are prioritized in relation to the price factor.

The following is a description of each criterion, justifying order of priority for scenario described by Specialist 2 and the form of evaluation defined:

a) Location (Zoning): the first filter for selecting a terrain is to check if it is possible to build in the zone in which it is located. After this analysis, location follows as the priority factor, but now 
Table 4. Criteria prioritization table by respondents.

\begin{tabular}{ccc}
\hline Priority & Specialist 1 & Specialist 2 \\
\hline 1 & Location $(Z o n i n g)$ & Location $($ Zoning $)$ \\
2 & Price $(\mathrm{R} \$)$ & Dimensions $\left(\mathrm{m}^{2}\right)$; Surroundings \\
3 & Dimensions $\left(\mathrm{m}^{2}\right)$ & Price $(\mathrm{R} \$)$ \\
4 & Surroundings & Form \\
5 & Form & Documentation \\
6 & Documentation & - \\
\hline
\end{tabular}

Source: Prepared by the authors (2015).

in the direction of the selected terrain being in a valued and commercially important zone. Since all terrains selected for the database are located in permitted zones for the buildings.

b) Dimensions $\left(\mathrm{m}^{2}\right)$ : directly influence the size of the building. For the present study there is no pre-defined type of building. In this way, the largest areas are considered the most valued.

c) Surroundings: the analysis of the environment is of extreme importance in the terrain selection as it portrays the development of the site to be built. For the present study, the measure defined to evaluate the surrounding is the Human Development Index (HDI) in the locality.

d) Price ( $R$ \$): is taken based on the above factors. It enters this position because it is negotiable, contrasting with a greater accuracy of the other factors.

e) Form: contemplates the geometric shape of the terrain and its slope. These variables do not influence much the purchase of the land, since the current technologies can adapt the projects to the most diverse forms of terrain.

f) Documentation: complex and variable depending on the location. It can be an impediment in the building, however there are rare cases of irregularities since the lands for sale usually have the updated documents.

Location, dimensions and surrounding are criteria for maximization. Thus, the greater the number of commercial zones, the larger the terrain dimensions, and the higher the HDI of the locality, the better. For the price criterion, it is sought to minimize the values of the alternatives, the lower the price, the better.

In the form and documentation criteria it is necessary to create a scale for better evaluation of the land. For documentation items vary between: a) Irregular; b) With restrictions, and c) Regular, The regular option is prioritized. For form, the variation occurs between: a) Irregular; b) Partially regular; c) Regular; d) Inclined; e) Slightly inclined, and f) Flat. The best evaluation for the form criterion results from the combination of the regular and flat factors.

For the construction of the database, the lands were selected from Canal do Imóvel (2015), a portal of great reference in online classifieds, from 2015, May 11 to 22, Access to data in a single search source seeks to minimize potential sources of misuse errors.

Found 73 land ( 63 residential and 10 commercial). For greater reliability of the results and an effective peer-to-peer comparison, the methods will be applied only to commercial land. After defining the criteria and the database to be used to evaluate the selected alternatives, it is applied to AHP and Fuzzy Logic methods application.

\subsection{Application of the AHP method}

The first step in the AHP method construction is the hierarchical structuring, represented by definition of the overall objective, criteria and alternatives for comparison. The hierarchical structure for commercial land selection in Rio de Janeiro city is represented by Figure 3.

With the hierarchical structure defined, a comparison was made along with the criteria, based on the fundamental scale proposed by Saaty and with the purpose of judging their order of importance.

For the definition of preference of the criteria were inserted weights according to the relevance given by the interviewee 2 to the criteria: dimensions, documentation, surrounding, form, location and price. The weights of the criteria and determination of consistency index can be visualized in Figure 4.

The consistency index for the criteria is acceptable, below the tolerance value 0.1 . The order of priority of the criteria in the terrain selection is also checked: location, surroundings, dimensions, price, documentation and form. With the order of importance of the criteria defined, the next step is to perform the comparison of selected alternatives.

In the first analysis the alternatives were compared according to the criterion dimensions $\left(\mathrm{m}^{2}\right)$. The consistency index obtained was 0.04090 , showing that the comparative values are within the acceptable value (below 0.1) and the preference 


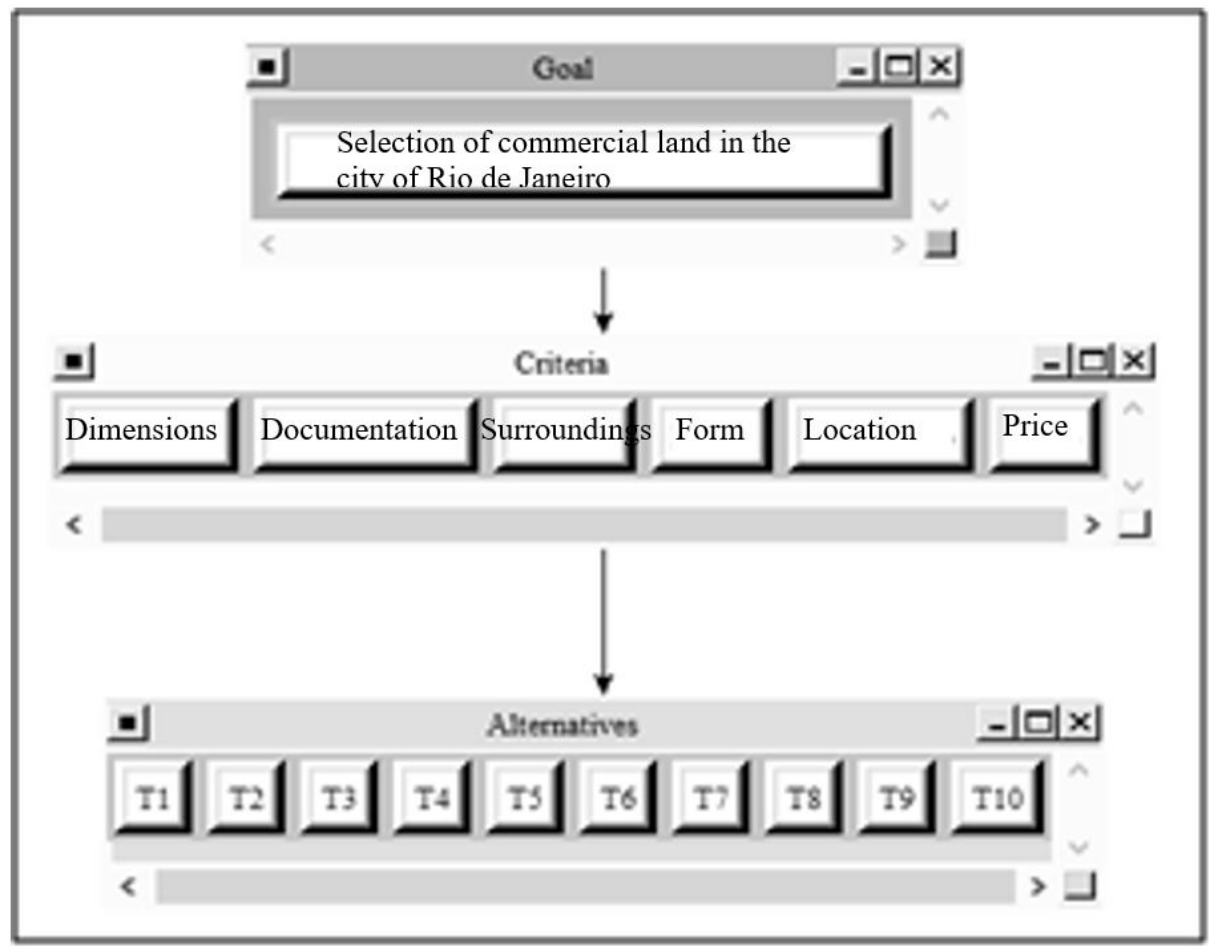

Figure 3. Hierarchical structure for selection of commercial land in the city of Rio de Janeiro. Source: Prepared by the authors (SuperDecisions), 2015.

\begin{tabular}{|l|l|l|}
\hline \multicolumn{3}{|c|}{ Inconsistency: 0.05855 } \\
\hline Dimensions & & 0.16729 \\
\hline Documentation & & 0.11826 \\
\hline Surroundings & & 0.21934 \\
\hline Form & & 0.03522 \\
\hline Location & & 0.32666 \\
\hline Price & & 0.13322 \\
\hline
\end{tabular}

Figure 4. Weight of the criteria and consistency index. Source: Prepared by the authors (SuperDecisions), 2015.

order of the alternatives for dimensions criterion is: $\mathrm{T} 7>\mathrm{T} 3>\mathrm{T} 6>\mathrm{T} 2>\mathrm{T} 10>\mathrm{T} 4>\mathrm{T} 5>\mathrm{T} 8>\mathrm{T} 1>\mathrm{T} 9$. In the second analysis, the alternatives were compared according to the documentation criteria. The consistency index obtained was 0.00611 and the order of priority of the alternatives for the documentation criterion is: $\mathrm{T} 1=\mathrm{T} 2=\mathrm{T} 3=\mathrm{T} 4=\mathrm{T} 5=\mathrm{T} 6=\mathrm{T} 8=\mathrm{T} 10>\mathrm{T} 9>\mathrm{T} 7$. In the third analysis, the alternatives were compared according to the surrounding criterion. The consistency index obtained was 0.03322 and the order of priority of the alternatives for the surrounding criterion is: $\mathrm{T} 2=\mathrm{T} 3>\mathrm{T} 1=\mathrm{T} 9>\mathrm{T} 5>\mathrm{T} 10>\mathrm{T} 4>\mathrm{T} 6=\mathrm{T} 8>\mathrm{T} 7 . \mathrm{In}$ the fourth analysis was carried out the comparison of the alternatives according to the form criterion, Consistency index obtained was 0.03002 and order of priority of the alternatives for the criterion form is: $\mathrm{T} 2=\mathrm{T} 3>\mathrm{T} 1=\mathrm{T} 6>\mathrm{T} 4=\mathrm{T} 5=\mathrm{T} 8=\mathrm{T} 10>\mathrm{T} 7=\mathrm{T} 9$.

In the fifth analysis, the alternatives were compared according to the location criterion. The consistency index obtained was 0.06865 and the order of priority of the alternatives for the location criterion is: $\mathrm{T} 2=\mathrm{T} 3>\mathrm{T} 1=\mathrm{T} 9>\mathrm{T} 4>\mathrm{T} 5>\mathrm{T} 6=\mathrm{T} 7=\mathrm{T} 8=\mathrm{T} 10$. In the sixth and final analysis the comparison of the alternatives according to the price criterion was performed. 
The consistency index obtained was 0.03019 and the order of priority of the alternatives for the price criterion is: $\mathrm{T} 8>\mathrm{T} 4>\mathrm{T} 1>\mathrm{T} 10>\mathrm{T} 5>\mathrm{T} 9>\mathrm{T} 7>\mathrm{T} 6>\mathrm{T} 2>\mathrm{T} 3$.

With the assignment of the weights to the criteria and the alternatives the global priority vector is defined, represented in Figure 5. For the scenario studied the best alternative is the terrain $\mathrm{T} 3$, and the final order of global priority is presented as: $\mathrm{T} 3>\mathrm{T} 2>\mathrm{T} 1>\mathrm{T} 4>\mathrm{T} 9>\mathrm{T} 7>\mathrm{T} 5>\mathrm{T} 10>\mathrm{T} 6>\mathrm{T} 8$.

\subsection{Application of Fuzzy Logic}

The first step in applying Fuzzy Logic is variables detailing. The criteria and their rules are transformed into linguistic terms to create degrees of pertinence of the alternatives within the corresponding fuzzy set.

The triangular shape was chosen to represent the membership functions. For the four most important criteria, five functions were created that allow greater precision and analysis of the results. The two least prioritized criteria were represented by three pertinence functions. For some criteria it is necessary to create a scale for better evaluation in the graph representing the functions. Thus, in each established range of the scale the pre-defined notes are designed linearly for better reliability of the values assigned to the alternatives. The general view of the fuzzy controller used is represented in Figure 6 , with the entry of the six criteria, the rules for the Mamdani controller and the output of the variables.In the dimension criteria the alternatives vary between 300 and $15,000 \mathrm{~m}^{2}$. A scale was created for a better evaluation due to the large variation of the values. In this way, the alternatives were adequate to the Fuzzy Set, according to Appendix A, which represents the pertinence functions.

The pertinence functions related to the dimensions criterion vary the alternatives between the terms "very small" and "very large". For the documentation criterion alternatives and functions of pertinence vary between terms "irregular" and "regular". A scale has been created for better judgment because of the interpretations that the terms can generate. In this way, the alternatives were adequate to the Fuzzy Set, which represents the pertinence functions.

For the criterion surrounding the alternatives vary, according to the local HDI, from 0.746 to 0.959 . The membership functions vary between the terms "very poor" and "great." The HDI values are evaluated directly, which represents the pertinence functions. Thus, it was not necessary to create a scale.

\begin{tabular}{|c|c|c|c|}
\hline Icon & Name & Normaliced by Cluster & $\longdiv { \text { timiting } }$ \\
\hline No lcen & TI & 0.11254 & 10056272 \\
\hline No Icon & 12 & 0.17923 & $\longdiv { 5 0 0 9 6 1 6 }$ \\
\hline No lcon & T3 & 0.18954 & 10094770 \\
\hline No Icon & $\mathrm{TA}$ & 0.00324 & $\longdiv { 0 . 0 4 4 4 6 8 }$ \\
\hline No icon & TS & 0.07637 & $\longdiv { 2 0 3 8 1 8 6 }$ \\
\hline No Icon & T6 & 0.06433 & $\longdiv { 0 . 0 3 2 1 6 3 }$ \\
\hline No Icon & 17 & 0.07370 & 10.036852 \\
\hline No icon & $\mathbf{T 8}$ & 0.06267 & $\longdiv { 0 . 0 3 1 3 3 6 }$ \\
\hline No Icen & T9 & 0.08723 & $\longdiv { 0 . 0 4 3 6 1 6 }$ \\
\hline No keon & $\mathbf{T} 10$ & 0.06544 & 0.032720 \\
\hline No Icon & Dimensions & 0.16729 & 200364 \\
\hline No icen & Documentation & 0.11826 & 0059132 \\
\hline No Icon & Surroundings & 0.21934 & $\longdiv { 0 . 1 0 9 6 7 2 }$ \\
\hline No lcon & Form & 0.03522 & 0017612 \\
\hline No Icon & Location & 0.32666 & 0.163331 \\
\hline No Icon & Price & 0.13322 & $\longdiv { 9 0 6 6 6 1 0 }$ \\
\hline No Icon & $\begin{array}{l}\text { Selection of land in } \\
\text { the citv of R.I }\end{array}$ & 0.00000 & $\longdiv { 0 . 0 0 0 0 0 0 }$ \\
\hline
\end{tabular}

Figure 5. Vector global priority and weight of the criteria. Source: Prepared by the authors (SuperDecisions), 2015. 


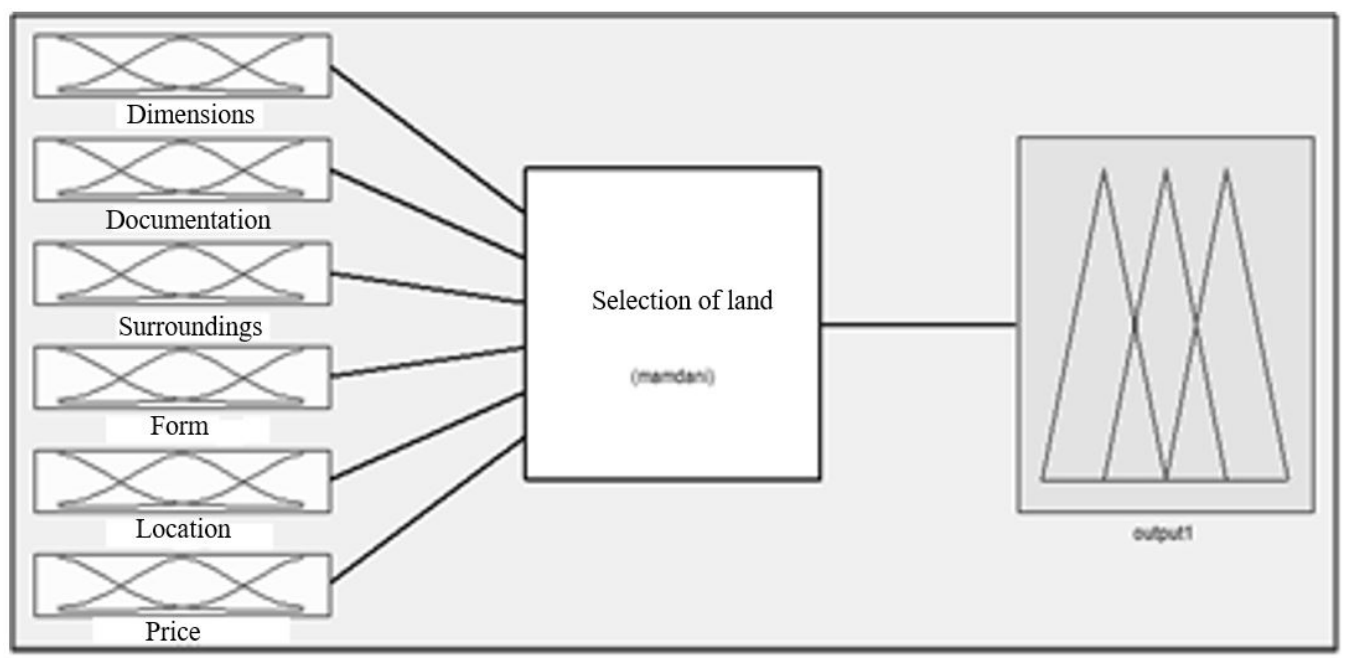

Figure 6. Fuzzy controller overview. Source: Prepared by the authors (MATLAB $\left.{ }^{\circledR}\right), 2015$.

For the form criterion that is divided into two parts: geometric form (form 1) and slope (form 2), the final marks result from the average of the two factors corresponding to the alternative. The pertinence functions related to form are verified, which vary the alternatives between the terms "irregular" and "regular". A scale was created to better evaluate the alternatives due to the innumerable interpretations that the linguistic terms can generate.

For the location criterion the alternatives vary according to the number of commercial zones, from 0 to 13 zones. Location-related pertinence functions vary the alternatives between the terms "very poor" and "optimal." A scale 5 was created for a better assessment due to the large difference between the number of commercial zones. In this way, the alternatives were adequate to what represents the pertinence functions.

For price criterion the alternatives vary from R \$ 850,000.00 to R \$ 17,965,000.00. Relevance functions related to the price criterion vary the alternatives between the terms "very high" and "very low". A scale was created for a better evaluation due to the large variation of the values. In this way, the alternatives were adequate to what represents the pertinence functions.

The output values for the fuzzy controller are ranked between the "very bad" and "optimal" language terms. In the Fuzzy Set represents all the output values for the evaluated alternatives.

The pertinence rules were created from the possible combinations between the factors and with the priority established by the interviewee 2 , generating adequate exit values based on the importance of each criterion. Two rules were generated for the "or" logical connective, described below:
A. Rule 1: If the documentation is patchy or the surrounding or location is too bad then the output value is very poor.

B. Rule 2: If the documentation is restricted or surrounding is poor then the output value is poor.

With the creation of rules for the logical connective "or", the alternatives with the worst evaluations in the most important criteria were related to the low output values. In this way, the number of logical combinations for the alternatives has decreased considerably.

The other rules, for the connective "e", for Dimensions, Surrounding, Location, Price and Exit the variation is from 1 to 5 , according to the linguistic terms and for Surrounding and Form the variation is from 1 to 3 .

Following the creation of pertinence rules, it is possible to evaluate results of the combination of factors for each alternative and prioritize the best output values. In Table 5, alternatives are related to their respective final values, we arrive at the final result with the output values indicated in the same table.

\subsection{Comparison of AHP and Fuzzy Logic methods}

For the two methods, the group of the first alternatives for selection was the same, following the order of importance: $\mathrm{T} 3>\mathrm{T} 2>\mathrm{T} 1>\mathrm{T} 4$, according to Table 6 .

Note that for the Fuzzy Logic the non-prioritized criteria have similar outputs. This is because of the rules created with the "or" logical connective, that for very low input values of the criteria "Surrounding", "Documentation" (criterion impedance if irregular) and "Location", the output will also be very low. In the AHP method, the comparison is made in a 
Table 5. Notes for evaluating the alternatives in the Fuzzy output.

\begin{tabular}{|c|c|c|c|c|c|c|c|}
\hline \multirow{2}{*}{ Land } & \multicolumn{6}{|c|}{ Criteria } & \multirow{2}{*}{$\begin{array}{l}\text { Output } \\
\text { Values }\end{array}$} \\
\hline & Dimensions & Documentation & Surroundings & Form & Location & Price & \\
\hline$T 1$ & 0.12 & 1.0 & 0.952 & 0.88 & 0.80 & 0.62 & 0.682 \\
\hline$T 2$ & 0.65 & 1.0 & 0.959 & 1.00 & 1.00 & 0.20 & 0.753 \\
\hline$T 3$ & 1.00 & 1.0 & 0.959 & 1.00 & 1.00 & 0.20 & 0.841 \\
\hline T4 & 0.32 & 1.0 & 0.831 & 0.75 & 0.70 & 0.64 & 0.655 \\
\hline$T 5$ & 0.22 & 1.0 & 0.901 & 0.75 & 0.60 & 0.53 & 0.627 \\
\hline T6 & 0.78 & 1.0 & 0.769 & 0.88 & 0.00 & 0.33 & 0.080 \\
\hline$T 7$ & 1.00 & 0.0 & 0.746 & 0.63 & 0.00 & 0.41 & 0.080 \\
\hline$T 8$ & 0.17 & 1.0 & 0.769 & 0.75 & 0.00 & 0.83 & 0.080 \\
\hline T9 & 0.12 & 0.5 & 0.952 & 0.63 & 0.80 & 0.47 & 0.250 \\
\hline$T 10$ & 0.39 & 1.0 & 0.857 & 0.75 & 0.00 & 0.59 & 0.080 \\
\hline
\end{tabular}

Table 6. Final classification of alternatives for AHP and Fuzzy.

\begin{tabular}{|c|c|c|c|c|}
\hline \multirow{2}{*}{ Land } & \multicolumn{2}{|c|}{ AHP } & \multicolumn{2}{|c|}{ FUZZY } \\
\hline & Relative Priorities & Ranking & Relative Priorities & Ranking \\
\hline$T 1$ & 0.11254 & $3^{o}$ & 0.682 & $3^{\circ}$ \\
\hline$T 2$ & 0.17923 & $2^{o}$ & 0.753 & $2^{o}$ \\
\hline$T 3$ & 0.18954 & $1^{o}$ & 0.841 & $1^{o}$ \\
\hline$T 4$ & 0.08894 & $4^{o}$ & 0.655 & $4^{o}$ \\
\hline$T 5$ & 0.07637 & $7^{\circ}$ & 0.627 & $5^{\circ}$ \\
\hline T6 & 0.06433 & $9^{\circ}$ & 0.080 & $7^{o}$ \\
\hline$T 7$ & 0.07370 & $6^{o}$ & 0.080 & $7^{o}$ \\
\hline$T 8$ & 0.06267 & $10^{\circ}$ & 0.080 & $7^{o}$ \\
\hline$T 9$ & 0.08723 & $5^{\circ}$ & 0.250 & $6^{o}$ \\
\hline$T 10$ & 0.06544 & $8^{\circ}$ & 0.080 & $7^{o}$ \\
\hline
\end{tabular}

Source: Prepared by the authors, 2015.

more lenient way, which allows a better definition of the non-prioritized criteria.

\section{Conclusions}

This work evaluated and classified land for commercial buildings from the creation of a database with alternatives located in Rio de Janeiro city, with reference to the use of methods of Decision Making. After surveying the characteristics of the selected alternatives, applying the methodology and analyzing the results, it was possible to conclude that:

A valid solution can be found for the decision of investments in land for commercial buildings, on the perspective of a buyer, through the application of the AHP method and Fuzzy Logic with the use of the software SuperDecisions and MATLAB ${ }^{\circledR}$.

The AHP method and the Fuzzy Logic revealed a hierarchy of the selected alternatives, allowing the classification of results in an optimized way.

The main classification results for the two methods were the same with the same priority classification for the first four alternatives, showing that the techniques, although different, can be used for the same purpose.

The prioritized alternatives have characteristics considered of extreme importance to the specialists interviewed, such as good location and surroundings, criteria that directly influence the valuation of buildings. The two best-evaluated alternatives, $\mathrm{T} 3$ and $\mathrm{T} 2$, are located in the Barra da Tijuca neighborhood, which has the highest HDI (0.959) and the largest number of commercial zones (13) among the alternatives.

It was also verified that the price criterion is represented by high values in the group of the best evaluated alternatives. This is justified by choosing the scenario that follows the prioritization of the factors for Expert 2, where price is not prioritized and immutable factors such as "Dimensions" and "Surrounding" are considered more important.

The alternatives with the worst evaluations are characterized by the lowest HDI values and have few or no commercial zones around their locations. In addition, some of these alternatives have impeding factors for construction as irregular or restricted documentation. 
The final result for the two applied decision-making methods responds to the research problem, and thus, the methods used can be considered satisfactory in the selection of commercial land in Rio de Janeiro city and tend to incorporate with clarity all the preferences. This can be observed in the analysis of prioritized lands, where all have the essential characteristics raised by the specialists.

Applied decision-making methodologies reach the overall goal. That is, they are generic and can be applied in the evaluation of any land, as long as all the necessary aspects for the decision process are incorporated to reach the final objective, thus facilitating the process of selection of land for buildings, establishing a scientific form for the decision-making process.

The specific objectives of the research: a) To study specific methods related to the decision making; b) Analyze the effectiveness of the decision-making methods evaluated, when applied, the selection of commercial lands in the city of Rio de Janeiro and, c) Make a comparative between the types of land from two (2) decision-making methods and to present a ranking of the alternatives according to the defined scenario were reached.

The research presented as a difficult and limiting factor the access to the land information, becoming a factor of greater difficulty to carry out the work. Many real estate companies do not have complete land data. Important information such as the specific dimensions (tested and depth) and the shape of the terrain have taken time to be rendered accurately, delaying the process of analysis and evaluation.

For the continuity of the study proposed in this work it is suggested the Analytic Network Process (ANP) application. In this way, the number of criteria can be broadened allowing a more specific evaluation. Another suggestion is to carry out the evaluation work without using the price factor, which can result in a new perspective of results. In addition, the present work demonstrated how the application of methods such as AHP and Fuzzy technique can make decision making in Civil Engineering more effective.

\section{References}

Arend, C. O., Oliveira, J. M. \& Ávila, L. (2011). Passivos ambientais (Dossiê Técnico). Porto Alegre: SENAI. Retrieved in 2015, July 1, from http://www.respostatecnica. org.br/dossie-tecnico/downloadsDT/NTY2Ng==

Barin, A. (2012). Seleção de sistemas de geração de energia elétrica a partir de resíduos sólidos urbanos: uma abordagem com a lógica difusa (Tese em Engenharia Elétrica). Universidade Federal de Santa Maria, Santa Maria.

Barin, A., Magnago, K. \& Abaide, A. R. (2010). Seleção de fontes alternativas de geração distribuída utilizando uma análise multicriterial baseada no método AHP e na Lógica Fuzzy. Revista Controle \& Automação, 21(5), 477-486.

Bertrand, J. W. M., \& Fransoo, J. C. (2002). Modeling and simulations: operations management research methodologies using quantitative modeling. International Journal of Operations \& Production Management, 22(2), 241-264. http://dx.doi.org/10.1108/01443570210414338.

Camposinhos R. S. (2006). Avaliação de Terrenos. Porto: Instituto para o Desenvolvimento Tecnológico. Retrieved in 2015, March 15, from https://www.academia.edu/ people $/$ search?utf $=\%$ E2 $\% 9 \mathrm{C} \% 93 \& q=\mathrm{CAMPOSIN}$ HOS $\% 2 \mathrm{C}+\mathrm{Rui}+\mathrm{de}+$ Sousa. + Avalia $\% \mathrm{C} 3 \% \mathrm{~A} 7 \% \mathrm{C} 3 \%$ $\mathrm{A} 3 \mathrm{o}+\mathrm{de}+$ Terrenos. +

Canal do Imóvel. (2015). Encontre o seu Imóvel. Retrieved in 2015, March 11, from http://www.kenlo.com.br/

Carvalho, A. \& Barreto, F. F. P. (2005). Programação arquitetônica em edificações de funções complexas. In Anais do II Seminário sobre Ensino e Pesquisa em Projeto de Arquitetura - PROJETAR 2005. Rio de Janeiro: UFRJ.

Confederação Nacional da Indústria - CNI. (2010). Pesquisa principais problemas das empresas de construção civil. Revista Sondagem da Construção Civil, 1(9), 1-6.

Costa, H. G. (2002). Introdução ao método de análise hierárquica: análise multicritério no auxílio à decisão. Niterói: UFF.

Faria, D. G. M. \& Augusto, O. Fo. (2013). Aplicação do Processo de Análise Hierárquica (AHP) no mapeamento de perigo de escorregamentos em áreas urbanas. Revista do Instituto Geológico, 34(1), 23-44.

Garcia, D. (2014). Sondagem indústria da construção. In Anais do LXXXVI Encontro Nacional da Indústria da Construção. Goiânia: Confederação Nacional da Indústria.

Garcia, K. C., Teixeira, M. G., Alves, C. C. \& Alves, R. N. (2007). Concepção de um modelo matemático de avaliação de projetos de responsabilidade social empresarial (RSE). Gestão e Produção, 14(3), 535-544.

Gartner, I. R. \& Gama, M. L. S. (2005). Avaliação multicriterial dos impactos ambientais da suinocultura no distrito federal: um estudo de caso. Organizações Rurais \& Agroindustriais, 7(2), 148-161.

Gomes L. F. A. M. (2007). Teoria da decisão (1. ed.). Rio de Janeiro: Thompson.

Gomes L. F. A. M., Araya, M. C. G. \& Carignano, C. (2004). Tomada de decisões em cenários complexos: introdução aos métodos discretos do apoio multicritério à decisão (1. ed.). Rio de Janeiro: Thompson.

Ho, W. (2008). Integrated analytic hierarchy process and its applications: a literature review. European Journal of Operational Research, 186(1), 211-228. http://dx.doi. org/10.1016/j.ejor.2007.01.004. 
Instituto Brasileiro de Geografia e Estatística - IBGE. (2014). Dados do Rio de Janeiro. Retrieved in 2015, March 10, from http://www.ibge.gov.br/.

Lachtermacher, G. (2007). Pesquisa operacional na tomada de decisões: modelagem em Excel. 4. ed. Rio de Janeiro: Elsevier.

Leite, O. G., \& Veloso, H. M. (2012). Processo decisório em investimentos financeiros na bolsa de valores: um estudo comparativo entre as análises técnicas e as fundamentalistas dos comportamentos e critérios de decisão. Revista Gestão \& Conhecimento. (Esp.), 384-403.

Marins, C. S., Souza, D. O. \& Barros, M. S. (2009). O Uso do Método de Análise Hierárquica (AHP) na tomada de decisões gerenciais: um estudo de caso. In Anais do XLI Simpósio Brasileiro de Pesquisa Operacional (pp. 17781788). Rio de Janeiro: Sociedade Brasileira de Pesquisa Operacional.

Marques, I. R., Barbosa, S. F., Basile, A. L. O. \& Marin, H. F. (2005). Guia de apoio à decisão em enfermagem obstétrica: aplicação da técnica da Lógica Fuzzy. Revista brasileira de enfermagem. 58(3), 349-354.

Mendel, J. M. (1995). Fuzzy logic systems for engineerings: a tutorial. IEEE, 83(3), 345-377.

Ministério da Educação e Cultura - MEC. (2000). Referenciais curriculares nacionais da educação profissional. Retrieved in 2015, April 10, from http:// portal.mec.gov.br/
Prodanov, C. C., \& Freitas, E. C. (2013). Metodologia do trabalho cientifico: métodos e técnicas da pesquisa e do trabalho acadêmico (2a ed.). Novo Hamburgo: Feevale.

Rainer, R. K. Jr \& Cegielski, C. G. (2012). Introdução a Sistemas de Informação (3a ed.). Rio de Janeiro: Elsevier.

Rio de Janeiro. Prefeitura da Cidade do Rio de Janeiro (2015). Dados Gerais - Características Geográficas. Retrieved in 2015, May 20, from: http://www.rio.rj.gov. $\mathrm{br} / \mathrm{web} /$ riotur/caracteristicas-geograficas/

Saaty, T. L., (1986). Axiomatic foundation of the analytic hierarchy process. Management Science, 32(7), 841855. http://dx.doi.org/10.1287/mnsc.32.7.841.

Saaty, T. L. (1991). Método de Análise Hierárquica. São Paulo: Makron Books do Brasil Editora Ltda.

Sistema Firjan. (2013). Publicações e Pesquisas - Construção Civil: Tendências tecnológicas na indústria de construção civil no segmento de edificações. Retrieved in 2015, April 10, from http://www.firjan.org.br/

Veras, M. (2014). Gerenciamento de projetos: Project Model Canvas (PMC) (1a ed.). Rio de Janeiro: Brasport.

Xavier, C. M. S., Xavier, L. F. S. \& Melo, M. (2014). Gerenciamento de Projetos de Construção Civil: uma adaptação da metodologia Basic Methodware (1a ed.). Rio de Janeiro: Brasport.

Zadeh, L. A. (1965). Fuzzy sets. Information and Control, 8(3), 338-353. http://dx.doi.org/10.1016/S00199958(65)90241-X. 
APPENDIX A. Fuzzy set.

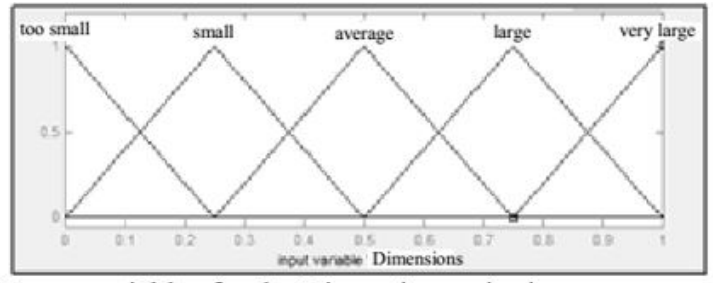

Fuzzy variables for the Dimensions criterion

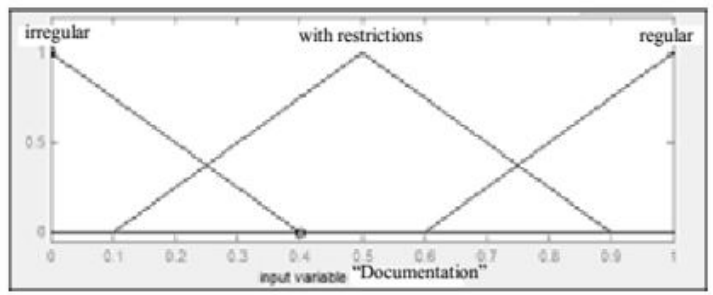

Fuzzy variables for the Documentation criterion

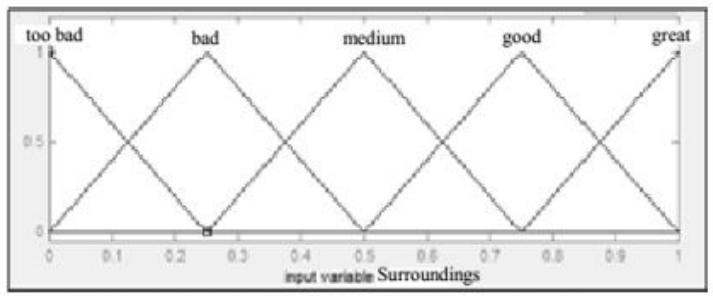

Fuzzy Variables for the Surrounding criterion

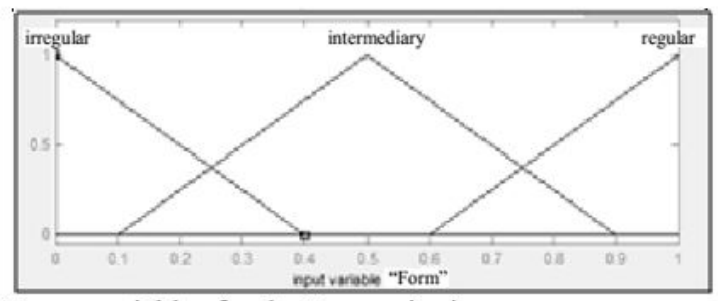

Fuzzy variables for the Form criterion

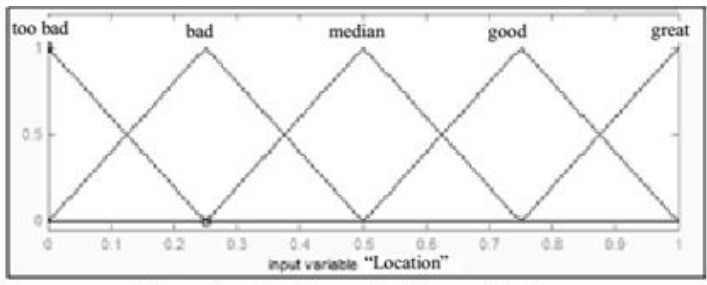

Fuzzy variables for the Localization criterion

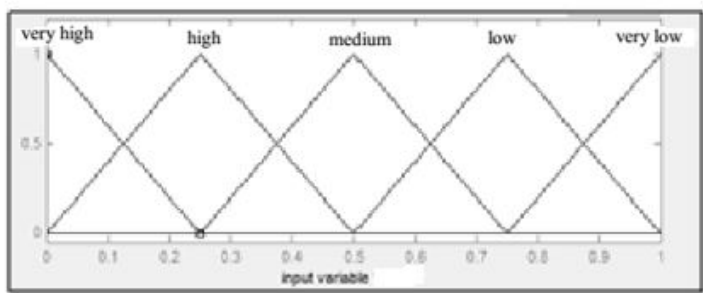

Fuzzy Variables for the Price criterion

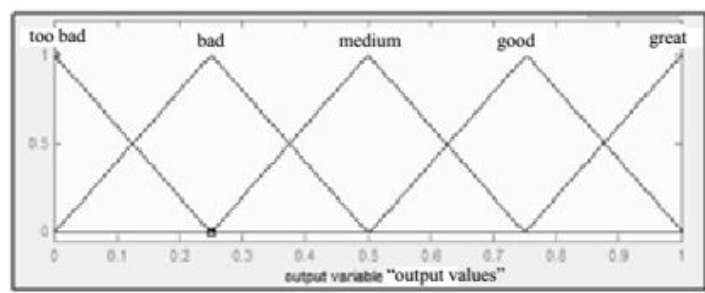

Fuzzy variables for output values

Source: Prepared by the authors (MATLAB $\left.{ }^{\circledR}\right), 2015$. 